\title{
Relationship, Structure, Values and Social Norms of Maiyah Juguran Syafa'at Community in Banyumas (Community Study)
}

\author{
Yuni Suprapto ${ }^{1}$, Melly Agustin ${ }^{2}$, Wasino ${ }^{3}$, Dewi Liesnoor Setyowati ${ }^{4}$, \\ Puji Hardati $^{5}$ \\ ${ }^{1}$ Primary School Education Study Program of Peradaban University, Brebes, Indonesia and Student \\ Postgraduate Social Studies UNNES, Semarang, Indonesia \\ ${ }^{2}$ Department of Social Studies Universitas Lambung Mangkurat, Banjar, Kalimantan and Student Postgraduate \\ Social Studies UNNES, Semarang, Indonesia, \\ ${ }^{3,4,5}$ Postgraduate Social Studies UNNES, Semarang, Indonesia \\ Corresponding Author: Yuni Suprapto
}

\section{ABSTRACT}

This research is based on a phenomenon of the Maiyah community in Banyumas, it is Juguran Syafaat who conducts recitation activities of a Sinau Bareng. This community is held 9 years ago so there are many worshipers who joint in these activities and they come from various background. Then the researcher interested in conducting research entitled the relations, structure, values and social norms of the Maiyah Juguran Syafaat community in Banyumas. The purpose of this study to reveal social relations, organizational structure, and social values and norms that exist in the Juguran Syafaat Community. This study uses a qualitative research method with a qualitative descriptive approach.

This research is a community study with data using interviews, participatory observation, text review and documentation in the routine activities of Sinau with Juguran Syafaat. The purpose of this research to reveal how the relationships, structures, values and social norms that exist in the jamaah maiyah (Juguran Syafaat). This type of qualitative approach, with data analysis, data reduction and data triangulation. The population of this research is the Juguran Syafaat community (activists, administrators or sedulur from other congregations). The results of the research, are the internal structure of the activist consisting the chairman and activists, while the social structure of the Jamaah Maiyah Juguran
Syafaat; includes students, political officials, businessmen, artists, and others. The results of the analysis, there is no structural distinction between the congregation, are not based on their role in work or economic strata, they discussed with "lesehan bareng". Social relations, they make relations with all elements of society they meet, during their sinau activities or, their daily activities. Values and norms have always been instilled by the maiyah community in Juguran Syafaat. Intercession is a religious value of sangkan paraning dumadi. The social value of the juguran intercession community to communicate \& socialize with all levels in a society. The norms that are always instilled are the customs and norms that exist in Java and Indonesia, for example, always using courtesy and respecting everyone.

Keywords: Relationships, Structure, Values and Norms, Maiyah Community, Juguran Syafaat

\section{INTRODUCTION}

Indonesia is a country which has various cultural resources in the world. Approximately Indonesia has 14,300 islands, more than 4,000 languages, and various religions and customs, this is an extraordinary potential for diversity and pluralism. However, after reform in 1998, exactly in 1999, Indonesian pluralism faded which is indicated by many radicalism movements and acts of terrorism and suicide 
bombings on behalf of religion, for example the Bali I Bombing, Bali II Bombings, JW Mariot suicide bombings etc., ten years after reformation, religious fundamentalist of radicalism movements and acts have strengthened, moreover in 2020 there are many fundamentalist activities, although they were carried out in social media. KOMINFO has blocked 814,594 radical sites (Kominfo, 2018) in 2010 to 2018 period. Regarding the strengthening of the Islamic fundamentalist movement in Indonesia which began in 1998, it is necessary, to counterbalance a movement or breakthrough in returning Islamic religion image in Indonesia as a rahmatan lil alamin religion, that loves peace and upholds plurality. Emha Ainun Najib is one of national figure who struggles in spreading peace-loving, pluralistic of Islam. In 1998 after reformation, he retire from national media, further well known as Cak Nun, is withdrawing from the national media after the 1998 reform era, Emha Ainun Najib, commonly called Cak Nun, intensified his preaching to all corners of Indonesia with a cultural frame, starting from Jombang which is his hometown, Cak Nun initiated the birth of the Maiyah Community of Padhang Bulan (Syarifudin, 2017), he attended and invited Sinau with the congregation once a month, this gave rise to discussion spaces (simpul maiyah) in other big cities, including Yogyakarta (Mocopat Syafaat), Kenduri Cinta (Jakarta) and the city of other. The development of maiyah nodes in all cities in Indonesia is increasing and so far, there are around 21 registered on caknun.com and it could be more because there are several cities that have maiyah nodes but have not been recorded (Caknun.com, 2020).

Purwokerto is a city as big as Semarang, with a heterogeneous human with metropolist population, so has dynamic development, especially the life of a pluralistic religious. There is one maiyah node which an active node that held a recitation known as Sinau Bareng every month in Banyumas Regency called Juguran
Syafaat (JS). The maiyah community is a social community examines the realities of life, there is an uniqueness activity of the maiyah, called Sinau Bareng, that everyone has the right to speak, all participant have the right to express the truth according to their respective, and no compulsion of expressed opinion, everyone has the the same freedom right to determine whether they agree or disagree, the maiyah pilgrims has a high awareness of each individual, so Sinau Bareng activities can run well (Pertiwi, 2018). Sinau Bareng activity is held with various themes and social studies on the Jama'ah Maiyah (JS), so researchers encourage and interested in conducting research entitled "Social Relations, Structure, Values and Norms of the Maiyah Juguran Intercession Community in Banyumas".

\section{LITERATURE REVIEW}

Afif, conducted a study entitled a picture of spiritual well-being in Yogyakata Jama'ah Maiyah, the results the study found that there were two factors that fulfilled the spiritual well-being fulfillment on the informants, they are internal factors such as relationships with God, beliefs and hopes, life experiences, crises and renewal, also success in achieving something. External factors include culture, exemplary, attendance intensity, Maiyah sense and personification. Also found the aspects of Jamaah Maiyah's spiritual well-being consist of personal, communal, environmental and transcendental.

There are differences and similarities of Yogyakarta Maiyah recitation Personal meaning in each congregation. Both KS and $\mathrm{HI}$ analogize that Maiyah recitation as an oasis in human life. AA analogizes the maiyah recitation as a huge container which able to accommodate anything. There is an automatically transferred energy in Yogyakarta Maiyah recitation which to Maiyah congregation. It has a direct impact to the congregation, so they feel fully regarged and ready in facing their respective lives (Ahmad Afif, 2018). 
Fauzi conducted research entitled multicultural education in maiyahan (Maiyah recitation activity) in Kidung Syafaat Salatiga City, the result of the study shows that there is a multicultural education which maintained and continuously developed in Maiyah community council of Kidung Syafaat Salatiga. This is reflected in every theme discussed and treated by the congregation in their recitation. Second, Maiyah Kidung Syafaat has a positive influence on the worshipers who attend the recitation, which showed in data found that multicultural education is applied by congregation in their daily behaviour and socialized to others. This achievement is influenced by the intensity of many delivered material, the atmosphere that created in Maiyah, promotes a sense of kinship and sharing (Fauzi, 2019).

Akmaliyah, also conducted a study entitled the impact of Emha Ainun Najib's spiritual thought in Jamaah Maiyah, in her research showed that Cak Nun's main spiritual teachings were sholawat and dhikr, the effect of doing those, felt positively for congregation's soul, heart, mind, life and career. They sholawat and dhikr in several places such as at home, when study, with sincerity and belief. They follow and carry out this practice, for their comfortness and calmness. They also feel changes after they carry out these practice (Nas'atul Akmaliyah, 2017).

Based on several prevous studies, there are similarities and differences with this study, the similarities are both analyzing the Maiyah community, and the same qualitative research approach. The difference is that this research takes structural theme, relations, values, and norms that exist in Banyumas Juguran Syafaat maiyah community, while previous study was conducted in Jogjakarta, Semarang and Surabaya. Then the next difference is that previous focused on spirituality and multicultural education while this research focus on structure, social relations, values and norms. The novelty of this research than previous study is to examine and dissect the phenomenon of the Maiyah juguran syafaat knot in Banyumas, in terms of relations, structure, values and social norms

\section{Social Structure Theory}

Social structure is the social relationships arrangement are embodied in a society, the social structure includes the relationship between individuals with one another and the social degree of individuals in society (Radcliffe-Brown, 1940). Evan Pritcjard propose that social structure is the relationship between individuals and groups in a broad unit (Pritchard, 1951). Pranoto said that social structure is a social order or arrangement that forms social groups in a society, social structure has a correlation with economic factors, social groups and social behavior (Pranoto, 2010). furthermore, Pranoto said, Tangirerung stated that social structure is a social building consisting of social elements which functionally related to each other, the structure has two forms; social stratification and social differentiation (Tangirerung, 2018). Based on experts' theory, social structure is the arrangement of social relations manifested by economic factors, groups, social behavior which is divided into social stratification and social differentiation. Then the social structure that will be investigated is how the social structure of Maiyah community in Juguran Syafaat Banyumas, the structure in Juguran Syafaat will be seen as an internal, and congregation's structure of the who participates in Sinau Bareng activities regularly, every month. In addition the social structure, this research will also analyze social relations, values and social norms existed in Juguran Syafaat Maiyah community in Banyumas.

\section{Relation Social Theory}

Social Relation, George Simmel said that social relations is the concept of reciprocity carried out by society, which is seen as more than just individuals, society as individuals who interconnected and 
influence each other and formed a society. According to him there are four focuses thought; macro analysis of individual psychology in social life, their second, they focus on interpersonal relationships or interactions between individuals, third, attention to the level of social and cultural structures, also the changes occurred in these structures. The fourth level is metaphysics (Community \& Rural, 2018). Simmel's view is same with him. Soekanto has different though regarding the forms of social interaction, according to him, social interaction is "cooperation, competition, conflict, and accommodation" (Soekanto, 2012). Based on the social relations theory, this study will analyze social relations in activists and Jamaah Maiyah Juguran Syafaat, relations will also be distinguished before and after the Covid 19 pandemic.

\section{Norm and Social Values Theory}

Value is something good, always be wanted, aspired and considered something important by people in the society. Therefore, something is valuable if useful and worth (truth value), beautiful (aesthetic value), good (moral or ethical value), religious (religious value) (Setyadi, 2019).

The function of social values has several that must be noticed in coexis; which seen from the point of view of human person formation as a society, the progress of society. Narwoko said that there are three points of view regarding the function of social values; a) as an encouragement, humans as actors are able to encourage the function of social values, means that in a value is able to encourage or strong energy in stimulating every normal people, this power can be awards of a positions, achievements, and everything of individuals activities; b) as a guide, means that every activity and way of human thinking is generally directed by social values prevailing in the society; c) as a fortress of protection, social values as values (processes) of various social activities existed in a society, they will try to defend these values, since if there is a disturbance on it, so it can broke the pattern prefailing in society (Narwoko, 2004). While Adisubroto said that value is a pattern of life attention, both individually and in groups, each individual or group usually has attention to certain values may be different from other individuals or groups, so according to Adi Subroto, values serve as a benchmark for society in upholding character and behavior patterns prevailing in a community (Adisubroto, 1993). The values that will be studied in this study are value of religiosity, social value, cultural value, and family value in Jama'ah Maiyah Juguran Syafa'at.

\section{MATERIALS \& METHODS}

This research type is qualitative research with a qualitative descriptive approach, data collection techniques using participatory observation, interviews, documentation, and literature studies. Data processing techniques using data reduction and data triangulation techniques, the object of this research is the Maiyah community at Juguran Syafaat node in Banyumas, research subjects of this study are maiyah activists and maiyah congregations.

\section{RESULT}

\section{A. Maiyah Juguran Syafa'at Community Profile}

Juguran Syafa'at is a maiyah node which is located in Banyumas. Here is the history of JS formation was delivered by AG; the history of Maiyah Juguran Syafa'at formation:

It was started from senior high school students' of SMA N 2 Purwokerto gathering, they were RK, AS, KK, beside they discussed with their schoolmate, also discussed various topics during the 20032005 period, this discussion was the embryo which later became the Maiyah Juguran Intercession knot. RK and friends in 2005 to 2006 period often attended the Caknun Kiai Kanjeng' (CNKK) recitation at Mocopat Syafaat Yogyakarta, Kenduri Cinta (Jakarta). During their lecturing break, RK together with other activists from Purbalingga were discussed the social 
community developments, and themes that CNKK and Kiai Kanjeng discussed at Sinau Bareng of Mocopat Syafaat, Gambang Syafaat and Kenduri Cinta. In 2010 RK, AG, KK, FB held a Cultural Workshop by gathering all communities in Banyumas Purwokerto entitled Cultural Workshop Unite Purwokerto, this cultural workshop was the forerunner of the Maiyah Juguran Syafa'at Knot. The cultural workshop is intended to all communities in Purwokerto, for example, Vespa community, Underground Music Community, the Culture and Arts Community, and others. The name Juguran Syafa'at was chosen because juguran means hangout or chatting, then Syafa'at is taken from the existing node, i.e Mocopat Syafa'at, Gambang Syafa'at and others. According to AG Syafa'at means the hope of God's blessing through Kanjeng Nabi's. The used place of Sinau Bareng Juguran Syafa'at activities, 1 to 30 edition was held at the Banyumas Deputy Regent's Hall, according to AG, at the first study, the activists were confused in finding an easy to accses place continuously. Then Mr. Titut (Purwokerto Artist) who often participates in Sinau Bareng activities, is a close friend of deputy regent that period, then activists ask for permission and help to him, and always include Mr. Titut in Sinau Bareng, then Sinau Bareng of 31 edition was no longer held in The Vice Regent's pavilion due to Regent's circular which define that gathering activities limited at $11 \mathrm{pm}$. Then Maiyah Juguran Syafa'at activities were held in other places, moving around, once held at Banyumas Scout Park (SKB Park), according to AG event Sinau Bareng at SKB often be cancelled, since there usualy held un expected event of scout, so they reschedule the event date. Sinau Bareng has also been held in courtyard of an Hotel in Baturaden, which one of the event that attended by so many pilgrim as ststed by AG. Then at 60th edition on March 2020, to the 86th edition Sinau Bareng activities was held in Deputy Regent's Hall, and fully suported by Pak Dewo (the recent Deputy
Regent). Then by Covid 19 Pandemic, the Sinau Bareng by Juguran Syafa'at was held by daring activities, via YouTube, then in 87th to 92nd edition in November 2020 the event took place on studio 4 Java Exposure Purwokerto, this studio is owned by FK one of Jamaah Maiyah member. The number of activists also been changes increase and decrease, AG stated that the number of activists usualy ups and downs, this is reasonable in the midst of their busy lives, for example there was a KS and JS who were very active in joining Sinau Bareng activities, However, these ups and downs have not diminished our enthusiasm, activists, congregations and others would always discuss and held Sinau Bareng activities. AG's statement was also confirmed by KR that the first initial formation of Sinau Bareng was held by only 7 people, they are activists and several congregations. The first leader of JS was AS, then RK and now the leader is HM.

$\mathrm{HM}$ as a leader said that before the covid 19 Juguran Syafa'at is well developed, there are about fourty to seventy people who routinely attended Sinau Bareng activity, Ki Ageng Kanjeng (KAJ) is a band of Juguran Syafa'at, which always accompanies Sinau Bareng activity, they also ready to accompany other communities, even cross-community and belief. Besides KAJ Juguran Syafaat also has social media such as Instagram, Twitter, Facebook, website of juguransyafaat.com. and Juguran Syafa'at Youtube Channel. KAJ was once participated in an event during the Chinese New Year event in Banyumas, this proves that Juguran Syafa'at provides benefits for all Banyumas and Indonesia people, not only for certain religion.

\section{B. The Structure of Juguran Syafa'at}

In this research the structure in Juguran Syafa'at congregation is divided into two: the Internal Structure of the Juguran Syafa'at Community and the Social Structure of the congregations who attend in Sinau Bareng activities. Here are the results: 


\section{Internal Structure of Juguran Syafa'at}

The management activists' structure of Juguran Syafa'at, there are; Head of the Maiyah node, then other activists, Since Maiyah is not a standard social organization, so there is no standard structure, at least only a leader and other sections. If the leader can't attend the event, other activists will ensure that the event of Sinau Bareng activities will run well even though without a leader. HM is now the leader of Juguran Syafa'at, previously were AS and RK, since their busyness and responsibility in their work, then bestowed to HM. Beside of chairman, there is another internal structure called activists which is voluntary and un-elected. AG is one of the voluntary activists which coordinate, manage and publish all JS activities.

For example, Publishing the theme of recitation in Sinau Bareng event, then creating a preamble for it, photography and also managing the JS website, by doing those, AG has self taught journalistic skill. Meanwhile, RK, is a person who responsible in providing ideas and prompts, he also usually provides a place for AS, KK, FB and other pilgrims which is usally gather on Tuesdays every week to discuss the developments in society and initiate discussion theme on Sinau Bareng in every month. Coordination is also carried out via social media of Facebook and WhatsApp.

The internal structure of Juguran Syafaat is very different from standard social organizations, in JS their respective jobs and function is done by their individual awareness, so there is no rigid and mandatory jobdesk, so easier in coordinating each division, this individual awareness makes collective work in Sinau Bareng activity which starts from discussing current social problems would be discussed in the event and determining the theme, preparing all tools equipment at the venue of Sinau Bareng event, and make sure that the event run well, this researcher saw when in 92nd of Sinau Bareng activity in November 2020, they cooperate among activists and worshipers who attended the event, although the activity was held in the studio and limiting the attendance of congregation, the event went smoothly, then they preparing broadcasting tools of on air event on YouTube channel, FK as the studio owner provides all needed tools, HM and AG participate in setting up these tools, that assisted by other congregations, KK provide homemade food for activists and other worshipers, SG and FB prepare coffee and snacks, this collective work is done by them not only for internal event of JS but also for event in other city, for example attending Sinau Bareng of CakNun and Kiai Kanjeng (CNKK) activities or visiting other member in other cities. So, the internal structure of JS is different from Pranoto's theory, the structure in JS more in line to Pritjhad's Theory, stated that individuals and groups of JS Maiyah congregation and activists, establishing a structure based on their same and broader interests, this only intended for Maiyah community's sustainability and continuity which has good contribution for wider community.

Here researcher attached the structure of Internal JS and activist with their background:

Tabel 1. Internal Structure of Juguran Syafaat

\begin{tabular}{|l|l|l|l|}
\hline NO & Initial & Structure Position & Ocupation \\
\hline 1 & HM & Leader of JS & Vilage leader \\
\hline 2 & FB & Moderator of Sinau Bareng & Minimarket owner \\
\hline 3 & RK & Activist & Exportir of ant Sugar \\
\hline 4 & AG & Activist (Publication) & Freelancer, Dropshipper, Honey Breeder \\
\hline 5 & KR & Event Moderator & Merchant \\
\hline 6 & SG & Activist & Barbershop Owner \\
\hline 7 & FK & Activist & Java Exposure Owner \\
\hline 8 & KK & Activist & T-Shirt Enterpreneur \\
\hline \multicolumn{3}{|c|}{ Source: Interview and Observation on November 2020 } \\
\hline \multicolumn{3}{|c|}{}
\end{tabular}

1) External Structure of Jamaah maiyah Juguran Syafaat
Community structur which participates in Maiyah Juguran Syafa'at 
activities. AG said that anyone can participate in Maiyah Juguran Syafa'at activities, when Sinau Bareng event is held, all levels of society can participate in all activities and discussions, even if there are atheists' people, they can participate in Sinau Bareng activities. There also governments structure who participate in the event, for example, the deputy regent and other SKPDs of Banyumas. Artists and culturalists also participate in Juguran Syafa'at activities, for example Mbah Hadi and Mr. Titut. College students, SMA 1 and SMA 2 students also participated in JS activities, then Slank, Regae and Underground community, had also participated in Sinau Bareng activities. Then there are other members of Juguran Syafa'at, for example from Purbalingga, Tegal, Sidoarjo, and Cilacap, according to $\mathrm{AG}$ there is something interesting during 2015 to 2016 since there are Christian congregations come from Purwokerto who has just moved from Jakarta, but they regularly attend Sinau Bareng activities until the event end.

The activists of JS are come from various educational backgrounds and jobs. For example, AG Bachelor of Management who works as an online shop reseller and honey entrepreneur. RK is a writer and distributor of coffee, chocolate and exporter of ant sugar. KK works as Structural of ASPIKMAS, KAR works as itinerant grocer. The pilgrims who attended the event were Mr. Titut, an artist and farmer. Mbah Hadi is a Banyumas Cultural. SG is the owner of a Barbershop in Purbalingga. So, the social structure and community who attend Sinau Bareng Juguran Syafa'at can be any one who come from any background for example, Students, Researchers, High School Students, Slank Community, Punk, Regae, even SKPD Pemda, and all community structures may participate in Sinau Bareng activities to discuss together related the up-to-date themes of community developments. The congregations their respective structures, also participate in the event of Sinau Bareng, for example those entrepreneurs of ginger or hot drinks serve their product during Sinau Bareng activity voluntarily, then who works as bakery serve bakers and snacks voluntarily in every Sinau Bareng activity. So, community structure according to their respective in Sinau Bareng activities which fit with capacities and expertise for good and smooth during the Sinau Bareng event, it is proven when the 92nd edition of Sinau Bareng on November 14, 2020, social structure in the Jama'ah Maiyah JS supports the theory of social structure presented by Pritchajd.

\section{Social Relation at Juguran Syafa'at Community}

Social relations of Jamaah Maiyah Juguran Syafa'at can be divided into:

\section{1) Activists Relation domiciled in Banyumas and Purbalingga}

The relationship between activists who live in Banyumas and Purbalingga not only occur during Sinau Bareng activities, but also in every time they get chance to interact, for example; on the past HM and AG said in early episode of JS activists from Banyumas were often visited Purbalingga, to US house as a leader. Since when AS was a leader, often invited fellow activists to discuss at his home (Purbalingga), to respond the current developments and formulate the theme of monthly event. According to $\mathrm{AG}$, the main purpose of relationships, interactions in JS is to develop the personal activists, and deepened during Sinau Bareng activities, the positive feedback to the pilgrims of their respective personalities, this is based on the results of participatory observations during episode 92 of Sinau Bareng in November 2020.

It can be seen that the social relations among activists are very close and warm relationship who dimiciled in Banyumas and Purbalingga, such as SG, which was found by the researchers when preparing Sinau Bareng activity at Studio 4 Java Exposure, that the activists cooperate without any command or order, they do their work on their own personal conscience. In addition to direct 
relationships and interactions, the activists also communicate via social media, such as WhatsApp, and phone or SMS on the past. They communicate in WA group, in Sinau Bareng activities for example, when visiting the AK, RK and HM's house, during meetings or discussions in determining the theme of the discussion study, they always apprize members of Jama'ah Maiyah from Purbalingga, Banyumas and Purwokerto.

\section{2) Relationship between Acticvists and Jama'ah Maiyah}

Relation between Jamaah with other congregations, and with maiyah nodes in other cities.

The relationship between activists and the Jama'ah Maiyah JS not only occur during Sinau Bareng activities, but also out of the event. AG said that there is no significant difference between activists and other Maiyah congregations, because there is no selection and appointment to become activists, actually activists and ordinary congregations are same, but activists fully awareness volunteered to help Juguran Syafa'at to be an activist. The social relations of Jama'ah maiyah and Juguran Syafa'at are not only based on certain background or structure, but rather on the interests of self-development and learning continuously for each member, AG's statement was strengthened by SG, SG said that as the owner of a barbershop, feels happy during Sinau Bareng activity since he can meet and interact with other member who have various professions and blend each other, lesehan (sitting down on a mat) during Sinau Bareng activities, that every member has the same right and opportunity to talk and discuss which enrich their knowledge. KK stated that in addition social relations between activists and congregations in Sinau Bareng event, it also occurred in their daily activities, i.e., those who have contact or phone numbers of other members will inquiry and inform them. In the event of Sinau Bareng, there were several worshipers who provided drinks, for example coffee, which could be up to 7
Waterjars for attendance of Sinau Bareng activities. Not only serve coffee, there are also activists who provide food, both snack and large meals for them. Interaction also occurred from other node's member with activists and congregations in JS, by joining Sinau Bareng activities, AG said that there is member of Gambang Syafaat, Maiyah node in Semarang who comes from Cilacap, when he gets back to Cilacap always inquiry members in JS Banyumas, and usually visiting them. The relationship which continuously built within all Jama'ah Maiyah is the result of Silatnas's (2019) appeal and direction which request 4 nodes that close each other to coordinate intensely and exchange ideas for pilgrim's independent and progress, for example, they able to establish joint economical business. If it is connected with social relations, so Jamaah Maiyah Juguran syafaat's social relation is the same as stated by George Simmel, that relationship between Jamaah Maiyah JS and activists is a reciprocal relationships and interactions, both among congregation's individual, or individuals with JS community, and vice versa. Then according to Soekanto who said that, social relations are based on associative relations, which are collaborations between maiyah congregations that carried out in order to Sinau Bareng activities running smoothly.

\section{3) Social relations of Jama'ah Maiyah JS in the Covid-19 Pandemic era.}

HM said that the COVID-19 pandemic has changed the relationship pattern of Jama'ah Maiyah JS, which usually their event of Sinau Bareng activity done directly by face to face meeting, nevertheless now they held that event only via social media such as WhatsApp, twitter, Instagram, Facebook, and YouTube, but for activities relationships apart in social media communication, they also communicate directly such as when they preparing Sinau Bareng activities in live streaming on YouTube, they cooperate each other in order to make the event well. By the existence of large-scale social restrictions, 
effected that not all of the activists able to participate during the live streaming, since the activist strictly implement health protocol which recommended by the government, by applying $3 \mathrm{M}$; Wearing masks, washing hands, and keeping a distance, this was reinforced when researchers attended the event and made participatory observations; setting the room by arranging the tables with the distance 1,2-2meters. In addition to the observations and opinions according to HM, KR stated that during the Sinau Bareng activity in the pandemic era when they felt sick and too tired, they did not attend the event directly, this was done according to government recommendations, if you feel sick to stay at home, which is feared will carry the the Covid 19 virus to the Sinau Bareng.

Completely, the Juguran Syafaat Maiyah Community's social relations were carried out are divided into three social relations between activists and other activists; first, social relations between congregations and activists, second, relations between congregations and other congregations, third, social relations between Jamaah Maiyah and the surrounding community.

\section{Values in Jama'ah Maiyah Juguran Syafa'at Community in Banyumas}

The existing values which always accustomed to the Jama'ah Juguran Syafa'at in Banyumas as follows:

KK said that there were many values that they got when joined with JS, such as knowledge of self-development, for example, when we discussed and listened to other congregations' stories, indirectly we got their knowledge which can be applied in our daily life. There was something interesting from this, for example, when Mr. Titut told about his childhood, he was playing kites in the fields, there were so many starlings that landed on cows or buffalo to eat grasshoppers which is a rice's pest, which they took an important role of food chain, unfortunately we now rarely find them in the field, from this we know that starlings are an organism model that takes important role of food chain which can cause the unstable food chain, since by it absence, the population of grasshoppers significantly increased. So, we know that we must preserve nature and environment by keeping the good food chain by not capturing and exploiting any organisms in food chain structure. KK's statement was strengthened by HM's story, by participating maiyahan (Sinau Bareng) activity we can learn about someone's' independence which told by other congregation, for example SG one of Jama'ah Maiyah JS member who comes from Purbalingga is very independent figure that really contributed to local community, HM said that even he is the owner of a barbershop, he helps his neighbours by selling their UMKM's product, for example cassava processed into chips, and many more, event a bicycle for sale at his barbershop. This was the embodiment of what Cak Nuns' teaching about being sovereign over yourself in various conditions ("Man of all the Season"). In addition of value of selfdevelopment by being sovereign over ourselves, the other value that always accustomed to the Jama'ah Juguran Syafa'at is the religious value, that told by AG, that every Maiyahan (Sinau Bareng) event is always opened by reading the holy Qur'an verses, then nariyah prayer, then just started the discussion of certain theme, which always associated to the verses contained in the holy Qur'an, that the point is how our lives is always related to Allah, whatever we do always present Allah, because the meaning of Maiyah is togetherness (with Allah), in accordance of Cak Nun said, "behind your desire there is God's will, then our task is to synergize the two". The other strong values in JS are Family values, which can be seen after researcher conduct this research which shown that, the value of kinship can be seen when they in daily interaction, when preparing the Sinau Bareng event, carrying out the Sinau Bareng activity, until the finish of the event. For example, when 
another member comes to JS base camp, they always welcome them and do not hesitate to help them. Another value, is plurality value (diversity), in JS there are various different backgrounds of congregations which is not prevent them to discuss in Sinau Bareng activities, AG said that Juguran Syafa'at is open to anyone who wants to develop themselves by discussing and increase knowledge through Sinau Bareng activities and other activities. Even if there are different beliefs, they can participate in Sinau Bareng activities.

\section{DISCUSSION}

1) The structure at the Juguran Syafa'at consists of Chairperson, Activists, and Jamaat, which come from various structural circles in society, and there is no limited to certain religion, nevertheless some of them are with different religions, and they participate in Sinau Bareng activities.

2) The Juguran Syafa'at's social relations are not only between activists and activists, activists with other congregations, but also relationships involved the community, then since the COVID-19 pandemic, it also uses social media such as WhatsApp to coordinate and YouTube for discussion in Sinau Bareng activities.

3) Values that are always emphasized Jamaaah Juguran Syafa'at are the knowledge value of self-development, religious, cultural, family, and plurality or diversity values.

4) If it is associated with social studies, how to prepare and create good citizens, in accordance with Juguran Syafa'at in structure, relations, and values that very relevant to the philosophy of social studies; how to become a good citizen, who pious, interact to all society, respect to national culture, promote democracy through Sinau Bareng discussion, always keep in improving knowledge and uphold unity in plurality framing.

\section{CONCLUSION}

The research that has been conducted on the Jama'ah Maiyah Juguran Syafa' at has the following conclusions:

1) The structure at the Juguran Syafa'at consists of Chairperson, Activists, and Jamaat, which come from various structural circles in society, and there is no limited to certain religion, nevertheless some of them are with different religions, and they participate in Sinau Bareng activities.

2) The Juguran Syafa'at's social relations are not only between activists and activists, activists with other congregations, but also relationships involved the community, then since the COVID-19 pandemic, it also uses social media such as WhatsApp to coordinate and YouTube for discussion in Sinau Bareng activities.

3) Values that are always emphasized Jamaaah Juguran Syafa'at are the knowledge value of self-development, religious, cultural, family, and plurality or diversity values.

4) If it is associated with social studies, how to prepare and create good citizens, in accordance with Juguran Syafa'at in structure, relations, and values that very relevant to the philosophy of social studies; how to become a good citizen, who pious, interact to all society, respect to national culture, promote democracy through Sinau Bareng discussion, always keep in improving knowledge and uphold unity in plurality framing.

\section{Suggestion}

Based on the results of research and discussion of suggestions from the results of this study are:

Based on the research outcome and discussion, recommendations of this research are:

1. Suggestions for further researchers, should conduct research with the object of Maiyah knots in other places or cities, in order to be able to enrich the 
scientific treasures in Maiyah community.

2. Suggestions for further research themes, is recommended to study the Maiyah community from anthropology point of view and ethnological studies with the cultural theme of thinking (logic) or other languages, with culture of tadabur

\section{Acknowledgement: None}

\section{Conflict of Interest: None}

\section{Source of Funding: None}

\section{REFERENCES}

1. Adisubroto. (1993). Nilai: Sifat dan Fungsinya. Psycology Buletin 1(2), 3.

2. Ahmad Afif. (2018). Rerpesentation of Spiritual Well-Being on Jamaah Maiyah Yogyakarta. UIN Sunan Kalijaga.

3. Caknun.com. (2020). simpul maiyah.

4. Fauzi, A. (2019). Pendidikan Multikultural dalam maiyah kidung syafaat Kot salatiga. IAIN Salatiga.

5. Kominfo. (2018). Kominfo Sudah Blokir 814.594 Situs Radikal.

6. Komunitas, D. I., \& Pedesaan, R. (2018). Relasi sosial antara kyai non politik dan kyai politik di komunitas religius pedesaan, $1-21$.

7. Narwoko, J. (2004). Sosiologi. Jakarta: Kencana.

8. Nas'atul Akmaliyah. (2017). Dampak Ajaran Spiritual Emha Ainun. Universitas Islam Negeri Sunan Ampel Surabaya.
9. Pertiwi, D. D. (2018). Maiyahan Sebagai Model Bimbingan Kelompok (Studi Kasus pada Komunitas Juguran Syafaat di Sokaraja Banyumas ). Institut Agama Islam Negeri ( IAIN ) Purwokerto.

10. Pranoto, S. W. (2010). Jawa Bandit-Bandit Pedesaan, Sutdi Historis 1850-1942. Yogyakarta: Graha Ilmu.

11. Pritchard, E. (1951). Social Anthropology. London: University of California Libraries.

12. Radclife-Brown. (1940). On Social Structure A. R. Radcliffe-Brown. "The Journal of the Royal Anthropological Institute of Great Britain and Ireland, 70(N).

13. Setyadi, B. (2019). Pariwisata Dan Perubahan Nilai-Nilai Sosial Budaya Berdasarkan Lingkungan Tradisi Pada Masyarakat Bali. Jurnal Penelitian Humaniora, 8(2), 5.

14. Soekanto, S. (2012). Sosiologi Suatu Pengantar. Jakarta: RajaWali Press.

15. Syarifudin, M. (2017). Konstruksi Identitas dan Ruang Publik Jamaah Maiyah Bangbang Wetan Surabaya. UIN Sunan Ampel Surabaya.

16. Tangirerung, L. (2018). Peran Struktur Sosial Masyarakat Lokal Dalam Pengelolaan Hutan Rakyat Di Desa Poton Kecamatan Bonggakaradeng Kabupaten Tana Toraja. UNHAS Makassar.

How to cite this article: Suprapto Y, Agustin M, Wasino et.al. Relationship, structure, values and social norms of maiyah juguran syafa'at community in banyumas (community study). International Journal of Research and Review. 2021; 8(10): 486-496. DOI: https://doi.org/10. 52403/ijrr.20211063 